저 $\square$

\title{
Seroidentification of Mycobacterium Tuberculosis by Enzyme-Linked Immunosorbent Assay
}

\author{
S.J. Kim, G.H. Bai, S.H. Lee, Y.K. Park and Y.P. Hong \\ Korean Institute of Tuberculosis, Korean National Tuberculosis Association
}

S.K. Lee

Seoul City Seodaemoon Hospital

K.Y. Kim, M.D. and Y.C. Han, M.D.

Tuberculosis Research Institute, Seoul National University Hospital

$=$ 국문초록 $=$

\section{酵素結合免疫分析法을 이용한 人型結核菌의 血清學的 同定 \\ 大韓結核協會 結核研究院 \\ 金晌材・韱吉漢・李承鎬・朴英吉・洪永构}

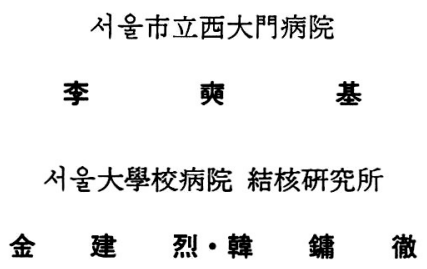

Mycobacterium tuberculosis $\left(\mathrm{H}_{37} \mathrm{Rv}\right)$ 에 대한 家兔免疫血清을 생산하여 $M$. kansasii 와 $M$. intracellulare 로 非特異抗體를 제거하므로써 人型結核菌에 대한 特異免疫血清을 제조하였다. 그 다음 Löwenstein-Jensen 培地에서 발육한 $\mathrm{H}_{37} \mathrm{Rv}$ 를 비롯한 人型結核菌 (39株), M. kansasii, M. scrofulaceum, M. avium, M. intracellulare, M. fortuitum 및 M. phlei 등을 石炭酸으로 死滅하여 세척 후 제조한 菌液을 特異免疫血清 과 반응시켜 特異抗體를 吸收한 후 人型結核菌을 吸着시킨 microtiter plate에 옮겨 殘餘 特異抗體를 측 정하므로써 환자로부터 分離培養되는 人型結核菌을 他抗酸菌과 鑑別할 수 있는지를 관찰하였다.

特異抗體 吸收에 이용된 菌의 양이 10 배 다른 두 濃度를 이용할 경우 吸光度 (optical density=OD) 의 감소는 현저하게 逆相關 關係를 나타내었다. 즉 L-J培地에서 발육한 $\mathrm{H}_{37} \mathrm{Rv} 1 \mathrm{mg} / \mathrm{ml}$ 및 $10 \mathrm{mg} / \mathrm{ml}$ 로 特 異抗血淸을 吸收한 경우 吸收전 $\mathrm{OD} 1.031 \pm 0.060$ 에서 각각 $0.658 \pm 0.025$ 및 $0.478 \pm 0.080$ 로 감소했다. 환자로부터 分離된 39 株로 吸收한 경우에는 $0.900 \pm 0.108$ 에서 각각 $0.754 \pm 0.116$ 및 $0.540 \pm 0.139$ 로 감 소했음에 비해 시험된 각종 非結核抗酸菌株들은 모두 유의한 양의 抗結核抗體를 吸收하지 않았다. 그러 므로 菌量을 $10 \mathrm{mg} / \mathrm{ml}$ 로 하여 特異抗血淸과 반응시켰을 때 人型結核菌은 $99 \%$ 가 반응전 血淸의 $\mathrm{OD}$ 를 $37 \%$ 이상 감소시키는데 비해서 非結核抗酸菌種들은 모두 $15 \%$ 미만밖에 감소시키지 못하였으므로 人型結 核菌을 他抗酸菌과 정확히 鑑別하는데 이와 같은 방법이 유용하게 이용될 수 있다고 생각한다. 


\section{INTRODUCTION}

Mycobacterium tuberculosis is of course a most important member of the genus Mycobacterium in its clinical significance. Hence utmost care must be paid to the fast and accurate identification of $M$. tuberculosis in the mycobacteriology laboratories. A number of methods have been introduced to differentiate $M$. tuberculosis from other mycobacteria. Now $M$. tuberculosis can be easily identified by simple one or two biochemical tests such as niacin test, heatlabile catalase test, and nitrate reduction test ${ }^{1,2)}$. If the growth of primary culture is not profuse enough to do biochemical tests, the susceptibility test to 500 $\mathrm{mcg} / \mathrm{ml}$ of para-nitrobenzoic acid is useful ${ }^{1}$.

In addition to these simple identification tests, a variety of immunological procedures have been extensively studied mainly for the taxonomic purpose, of which some have been found not only helpful to elucidate the antigenic differences in inter or intra-species of mycobacteria, but also to understand humoral as well as cell-mediated immunity of tuberrculosis ${ }^{3 \sim 6)}$.

In this study we have compared absorptions of $M$. tuberculosis specific antibodies present in the antiserum by the clinical isolates of $M$. tuberculosis and by non-tuberculous mycobacteria using the enzymelinked immunosorbent assay (ELISA) in order to find out a possibility of seroidentification of human tubercle bacilli. And we hope it may be able to lead a feasible access to the seroidentification of mycobacterial species or strains which are fastidious to identify by the current techniques.

\section{MATERIALS and METHODS}

\section{Mycobacterial Strains}

Mycobacterial strains used in this study are as follows. A reference strain $\mathrm{H}_{37} \mathrm{Rv}$ and 39 clinical isolates of $M$. tuberculosis from Korean patients, 3 strains of M. kansasii (KIT20002, 20003, 20007), 4 strains of M. scrofulaceum (KIT30001, 30101, 30006, 30008), 3 strains of $M$. avium (KIT 40001, 40002, 40004), 5 strains of $M$. fortuitum (KIT60001, 60002, $60003,60004,60102$ ), and 2 strains of $M$. phlei (KIT63002, 63003) were subcultured on LöwensteinJensen (L-J) medium. The bacterial cells were killed with $2 \%$ phenol and then washed with $0.067 \mathrm{M}$ phosphate buffered saline(PBS, $\mathrm{pH}$ 7.0) before use in the ELISA tests.

\section{Preparation of Rabbit Antiserum Specific to M. Tuberculosis}

Anti-M. tuberculosis $\left(\mathrm{H}_{37} \mathrm{Rv}\right)$ serum was raised in rabbits as described elsewhere ${ }^{7)}$. M. tuberculosis specific antiserum was prepared by absorbing the rabbit hyperimmune serum with $100 \mathrm{mg}$ of cells of $M$. kansasii and $M$. intracellulare and of smashed L-J medium. From the preliminary study it was found that $M$. kansasii and intracellulare could remove all possible cross reactive antibodies to mycobacteria other than $M$. tuberculosis present in the rabbit antituberculous serum. The absorbed specific serum was diluted to 1:100 for use in ELISA.

\section{Preparation of Bacterial Suspensions}

1) A reference strain $\mathrm{H}_{37} \mathrm{Rv}$ of $M$. tuberculosis was cultured as surface pellicle on Sauton's broth medium for $3-5$ weeks at $37^{\circ} \mathrm{C}$ and then killed with 2 $\%$ phenol. The bacterial mass was separated from culture broth and washed with PBS three times. Then the cell mass was homogenized with tissue homogenizer and washed again with PBS prior to use for coating the plate and for the control organisms in the standard homologous absorption.

2) Mycobacterial cells grown on the egg-based medium were transfered into $1 / 2$ ounce glass bottle containing 5- 6 glass beads ( $3 \mathrm{~mm}$ in diameter) and then homogenized and killed with $2 \%$ phenol. The killed cell suspension was washed three times in PBS. 


\section{Enzyme-linked Immunosorbent Assay}

1) The $\mathrm{H}_{37} \mathrm{Rv}$ cells grown on Sauton's broth medium were suspended to a concentration of $2 \mathrm{mg} /$ $\mathrm{ml}$ in coating buffer and $150 \mu \mathrm{l}$ of cell suspension was transfered into each well of microtiter plate (Linbro) and then overnight at $4^{\circ} \mathrm{C}$ for adsorption of the cells on the plate well. The plates were washed with distilled water (DW) and the residual binding sites were blocked with $0.5 \%$ bovine serum albumin (BSA) in a carbonate buffer. Then plates were washed with PBS containing tween 80 (PBST).

2) Rabbit antiserum specific to $M$. tuberculosis was diluted to 1:100 with PBST containing BSA (PBSBT) and reacted with $0.5 \mathrm{mg}$ or $5 \mathrm{mg} / \mathrm{ml}$ of $\mathrm{H}_{37}$ $\mathrm{Rv}$ cells and with $1 \mathrm{mg}$ or $10 \mathrm{mg} / \mathrm{ml}$ of test strains for 2 hours at $37^{\circ} \mathrm{C}$ and then bacilli were removed by centrifugation at $5,000 \mathrm{rpm}$. The $150 \mu \mathrm{l}$ of the supernatant together with unabsorbed serum was transfered into the wells of $\mathrm{H}_{37} \mathrm{Rv}$ coated plates and reacted at $37^{\circ} \mathrm{C}$ for 1.5 hours, followed by another 1 . 5 hours reaction with goat anti-rabbit IgG peroxidase conjugated immunoglobulin diluted to 1:400 in PBSBT containing normal rabbit serum. The enzyme conjugate was prereacted with $\mathrm{H}_{37} \mathrm{Rv}$ cells and egg homogenate to remove nonspecific reaction. After reaction with enzyme conjugate dilution, the plates were washed three times with PBST without $\mathrm{NaN}_{3}$ and $200 \mu \mathrm{l}$ of enzyme substrate ( $0.01 \%$ OPD) was added into each well and reacted for 15 minutes. The enzyme reactions were stopped by adding $50 \mu \mathrm{l}$ of $4 \mathrm{~N} \mathrm{H}_{2} \mathrm{SO}_{4}$ and the optical densities (OD) of reactants were read at $492 \mathrm{~nm}$ using Titertek Multiskan Spectrophotometer (Flow Laboratories Inc.).

\section{RESULTS}

Mean optical density (OD) of unabsorbed antiserum specific to $M$. tuberculosis was $0.900 \pm 0.108(0.803$ $\sim 0.996,95 \%$ confidence limit), but homologous absorptions with $0.5 \mathrm{mg}$ and $5 \mathrm{mg} / \mathrm{ml}$ of $\mathrm{H}_{37} \mathrm{Rv}$ cells. grown on Sauton's medium decreased OD to $0.390 \pm$ $0.045(0.350 \sim 0.430,95 \%$ confidence limit) and $0.146 \pm$ $0.044(0.116 \sim 0.196,95 \%$ confidence limit) as seen in table 1 . The difference of OD (0.244) between two bacterial concentrations was significant $(\mathrm{p}<0.05)$. Decrease of OD with increase of bacterial concentration for absorption showed a clear-cut reciprocal correlation. When the bacterial cell amounts (mg) were transformed into logarithms, linear regression equation ( $\mathrm{y}=0.4354-0.2323 \mathrm{x}, \mathrm{r}=-0.9515)$ was obtained as seen in figure 1.

The $\mathrm{H}_{37} \mathrm{Rv}$ cells grown on L-J medium, however, absorbed out less amount of antibodies than the cells grown on Sauton's medium, showing that ODs of antiserum were $0.658 \pm 0.025$ and $0.478 \pm 0.080$ when absorbed with $1 \mathrm{mg}$ and $10 \mathrm{mg} / \mathrm{ml}$ of the cells. One $\mathrm{mg} / \mathrm{ml}$ of the cells decreased $36.2 \%$ of OD of unabsorbed serum and $10 \mathrm{mg} / \mathrm{ml}, 53.6 \%$, while $0.5 \mathrm{mg}$ and $5 \mathrm{mg} / \mathrm{ml}$ of the cells grown on Sauton's broth medium decreased $59.6 \%$ and $82.4 \%$ of OD of antiserum respectively.

Table 1. Mean Optical Densities (OD) of Rabbit Antiserum Specific to M. Tuberculosis before and after Absorbed with $\mathrm{H}_{37} \mathrm{Rv}$ or 39 Clinical Isolates

\begin{tabular}{lccc}
\hline \multirow{2}{*}{ Strains } & \multicolumn{3}{c}{ Bacterial concentrations (mg/ml) } \\
\cline { 2 - 4 } & 0 & 1 & 10 \\
$5 *$ & $0.5 *$ & $0.146 \pm 0.044$ \\
\hline $\mathrm{H}_{37}$ Rv grown on Sauton's medium (8 tests) & $0.900 \pm 0.108$ & $0.390 \pm 0.045$ & $0.478 \pm 0.080$ \\
$\mathrm{H}_{37}$ Rv grown on L-J medium (3 tests) & $1.031 \pm 0.060$ & $0.658 \pm 0.025$ & $0.540 \pm 0.139$ \\
39 clinical isolates grown on L-J medium & $0.900 \pm 0.108$ & $0.754 \pm 0.116$ & \\
\hline
\end{tabular}

* $\mathrm{H}_{37} \mathrm{Rv}$ cells grown on Sauton's medium used for antiserum absorption were 0.5 or $5 \mathrm{mg} / \mathrm{ml}$, and the amounts of cells grown on L-J medium used for absorption were 1 or $10 \mathrm{mg} / \mathrm{ml}$. 
When antiserum was absorbed with $1 \mathrm{mg}$ or 10 $\mathrm{mg} / \mathrm{ml}$ of the cells of 39 clinical isolates, mean ODs were $0.754 \pm 0.116 \quad(0.717 \sim 0.792, \quad 95 \%$ confidence limit) and $0.540 \pm 0.139(0.495 \sim 0.585,95 \%$ confidence limit) respectively, while OD of control unabsorbed serum was $0.900 \pm 0.108$. Therefore mean OD of unabsorbed antiserum decreased $18.9 \%$ by the absorption with $1 \mathrm{mg} / \mathrm{ml}$ of the cells and $42.2 \%$ by 10 $\mathrm{mg} / \mathrm{ml}$. The ODs of antiserum and absorbed cell amounts were also reciprocally correlated $(\mathrm{y}=0$. $6938-0.1132 \mathrm{x}, \mathrm{r}=-0.9557)$. The difference of $\mathrm{OD}$

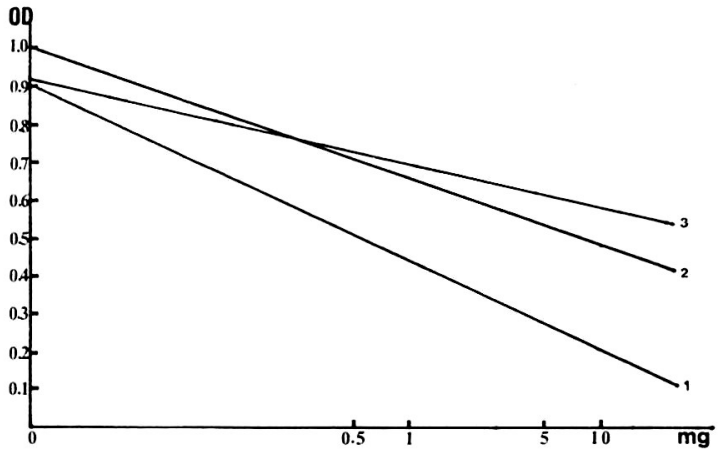

Fig. 1. Changes in mean optical density of $M$. tuberculosis specific antiserum according to cell amounts (mg) úsed in absorption.

1. Linear regression of antiserum absorbed with $\mathrm{II}_{37} \mathrm{Rv}$ cells grown on Sauton's medium ( $\mathrm{y}=$ $0.4354-0.2323 x, r=-0.9515)$.

2. Linear regression of antiserum absorbed with $\mathrm{H}_{37} \mathrm{Rv}$ cells grown on Löwenstein-Jensen medium $(y=0.6608-0.1846 x, r=-0.9999)$.

3. Linear regression of antiserum absorbed with clinical isolates grown on Lö wenstein-Jensen mediun $(y=0.6938-0.1132 x, r=-0.9557)$. between two bacterial concentrations was 0.214 on an average. However the difference was no more than 0.130 in 6 strains of $M$. tuberculosis, although their absorption of specific antibodies was still significantly larger than those of the other species. Mean decrease (\%) of OD of antiserum when absorbed with $10 \mathrm{mg} / \mathrm{ml}$ of the cells was $42.2 \pm 11.8 \%$ (37.1 47.3\%, 99\% confidence limit), indicating that $99 \%$ of $M$. tuberculosis cells would decrease more than $37 \%$ of OD of antiserum.

The bacterial cells of the other species did not virtually absorb out antituberculous antibodies in the specific antiserum even with $10 \mathrm{mg} / \mathrm{ml}$ of the cells $(p>0.10, t=1.2078)$ as seen in table 2. Mean difference of OD between two bacterial concentrations was merely 0.034. M. kansasii cells did not decrease OD of antiserum showing $0.860 \pm 0.066$ before absorption and $0.878 \pm 0.073$ and $0.855 \pm 0.027$ after absorption with $1 \mathrm{mg}$ and $10 \mathrm{mg} / \mathrm{ml}$ respectively. There were some slight decrease in OD when the antiserum was absorbed with $10 \mathrm{mg} / \mathrm{ml}$ of certain strains of $M$. avium or intracellulare.

Mean decrease (\%) of OD of antiserum was $3.8 \pm 3$. $5 \%, 4.8 \pm 2.7 \%, 6.6 \pm 3.4 \%, 6.3 \pm 4.2 \%, 3.8 \pm 3.5 \%$, and $-0.9 \pm 0.7 \%$ respectively when absorbed serum with $10 \mathrm{mg} / \mathrm{ml}$ of $M$. kansasii, scrofulaceum, avium, intracellulare, fortuitum, and phlei. Thus $99 \%$ of $M$. tuberculosis decreased more than $37 \%$ of OD of unabsorbed antiserum when absorbed with $10 \mathrm{mg} / \mathrm{ml}$ of the cells, while all the other species decreased less

Table 2. Mcan Optical Densities (OD) of $M$. Tuberculosis Specific Antiserum before or after Absorption with the Cells of Nontuberculous Mycobacteria

\begin{tabular}{lccc}
\hline \hline \multirow{2}{*}{ Species } & \multicolumn{3}{c}{ Bacterial concentrations (mg/ml) } \\
\cline { 2 - 4 } & 0 & 1 & 10 \\
\hline M. kansasii (3 strains) & $0.860 \pm 0.066$ & $0.878 \pm 0.073$ & $0.855 \pm 0.027$ \\
M. scrofulaceum (4 strains) & $0.806 \pm 0.017$ & $0.799 \pm 0.030$ & $0.771 \pm 0.035$ \\
M. avium (3 strains) & $0.808 \pm 0.024$ & $0.806 \pm 0.039$ & $0.755 \pm 0.034$ \\
M. intracellulare (5 strains) & $0.826 \pm 0.071$ & $0.801 \pm 0.086$ & $0.773 \pm 0.069$ \\
M. fortuitum (5 strains) & $0.902 \pm 0.013$ & $0.908 \pm 0.012$ & $0.872 \pm 0.016$ \\
M. phlei (2 strains) & $0.809 \pm 0.022$ & $0.811 \pm 0.035$ & $0.776 \pm 0.016$ \\
\hline
\end{tabular}


Table 3. Percentage Decrease of Optical Density of $M$. Tuberculosis Specific Antiserum by the Absorption of Homologous and Heterologous Mycobacteria

\begin{tabular}{|c|c|c|}
\hline \multirow{2}{*}{ Species } & \multicolumn{2}{|c|}{ Bacterial concentrations (mg) } \\
\hline & 1 & 10 \\
\hline M. tuberculosis, $\mathrm{H}_{37} \mathrm{Rv}^{*}$ & $59.6 \pm 8.3 \quad(59.6 \pm 6.9)$ & $82.4 \pm 6.2(82.4 \pm 5.2)$ \\
\hline M. tuberculosis, $\mathrm{H}_{37} \mathrm{Rv} * *$ & $36.2 \pm 2.4 \quad(36.2 \pm 6.0)$ & $53.6 \pm 4.0(53.6 \pm 9.9)$ \\
\hline M. tuberculosis, clinical & $18.9 \pm 7.7 \quad(18.9 \pm 2.5)$ & $42.2 \pm 11.8(42.2 \pm 3.8)$ \\
\hline isolates & {$[18.9 \pm 3.4]$} & {$[42.2 \pm 5.1]$} \\
\hline M. kansasii & $-1.4 \pm 1.4(-1.4 \pm 3.5)$ & $3.8 \pm 3.5(3.8 \pm 8.7)$ \\
\hline M. scrofulaceum & $1.1 \pm 1.7 \quad(1.1 \pm 2.7)$ & $4.8 \pm 2.7(4.8 \pm 4.3)$ \\
\hline M. avium & $1.0 \pm 1.1 \quad(1.0 \pm 2.7)$ & $6.6 \pm 3.4(6.6 \pm 8.4)$ \\
\hline M. intracellulare & $2.9 \pm 2.1 \quad(2.9 \pm 2.6)$ & $6.3 \pm 4.2(6.3 \pm 5.2)$ \\
\hline M. fortuitum & $0.8 \pm 1.4 \quad(0.8 \pm 1.7)$ & $3.8 \pm 3.5(3.8 \pm 4.3)$ \\
\hline M. phlei & $0.1 \pm 0.4 \quad(0.1 \pm 3.6)$ & $-0.9 \pm 0.7(-0.9 \pm 6.3)$ \\
\hline
\end{tabular}

* $\mathrm{H}_{37}$ Rv cells grown on Sauton's medium

** $\mathrm{H}_{37} \mathrm{Rv}$ cells grown on $\mathrm{L}-\mathrm{J}$ medium

( ) $=95 \%$ confidence intervals. $[\quad]=99 \%$ confidence intervals

than $15 \%$ (Table 3 ).

\section{DISCUSSION}

In practical aspects there are no difficulties in identification of $M$. tuberculosis isolated from clinical sources because one or two biochemical tests suffice to discriminate most of $M$. tuberculosis isolates from other mycobacteria ${ }^{1,22}$. The present study aimed not to replace the conventional identification techniques with new method, but to add some novel procedures if any.

Serological procedures such as ELISA are not simple techniques and not easy to standardize, however some of them permit to analyse the quantitative differences of antigenic relationship between species or even strains. This study showed that $M$. tuberculosis specific antiserum, prapared by absorbing out all possible cross reactive antibodies, was found useful to discriminate this species from other mycobacteria with an acceptable precision either by comparison of OD difference between two bacterial cell concentrations used to absorb out antituberculous antibodies present in the specific antiserum or by comparison of decreasing percentage of OD after absorption with control and test organisms. It seems to be applicable to the identification of classification of certain members of mycobacteria, which cannot be easily identified or classified by the conventional techniques.

The results showed that if OD difference between two absorption cell concentrations of test organism is more than 0.20 , it falls absolutely in $M$. tuber culosis, but in cases of anywhere inbetween 0.10 to 0 . 20 it may be tubercle bacilli but needs confirmatory tests. If the difference is less than 0.10 of $\mathrm{OD}$, test strain may fall in other mycobacteria. Six strains of $M$. tuberculosis showed $0.10-0.20$ OD differences, probably due to the paucity of their cell concentrations or due to possess of different amount of sharing antigens on the cell surface. Even $\mathrm{H}_{37} \mathrm{Rv}$ grown on L-J medium absorbed out less amount antibodies than the cells grown on Sauton's medium. This might also be resulted from the different cell amounts or from different amount of sharing antigens on the cell surface.

Another way of analysis is comparison of percentage of OD decrease on the basis of difference in OD 
of antiserum before and after absorption. This approach seem to be simple and better if the amount of cells can be standardized. While absorbed antiserum with $10 \mathrm{mg} / \mathrm{ml}$ of the cells of $M$. tuberculosis decreased $O D$ value of unabsorbed serum by more than $37 \%$, the almost all of other mycobacteria decreased by less than $15 \%$.

Over-all finding suggests that this technique may adapt fairly well to the other mycobacteria which are not easy to identify or classify by the conventional techniques.

\section{SUMMARY}

Rabbit anti- $M$. tuberculosis hyperimmune serum was absorbed with the cells of $M$. kansasii and intracellulare to remove all possible cross reactive antibodies and the specific antiserum has been studied to use a possible seroidentification of $M$. tuberculosis by ELISA. When the specific antiserum was absorbed with 1 or $10 \mathrm{mg} / \mathrm{ml}$ of homologous cells, OD (1.031) of unabsorbed serum decreased to 0 . 658 or 0.478 respectively and, when absorbed with 39 clinical isolates, to $0.754 \pm 0.116$ or $0.540 \pm 0.139$ respectively, while all other species did not absorb out any significant amount of antituberculous antibodies present in the specific antiserum. Thus if the specific antiserum was absorbed with $10 \mathrm{mg} / \mathrm{ml}$ of the cells, $99 \%$ of $M$. tuberculosis isolates decreased OD value of unabsorbed serum to more than $37 \%$, while all the other nontuberculous mycobacteria decreased to less than $15 \%$.

\section{REFERENCES}

1) Wayne GH, Engel HWB, Grassi C, Gross W, Hawkins J, Jenkins PA, Kappler W, Kleeberg $\mathrm{HH}$ : Highly reproducible techniques for use in systematic bacteriology in the genus Mycobacterium: Tests for niacin and catalase and for resistance to isoniazid, hydroxylamine and p-nitrobenzoate. Int J Syst Bacteriol 26:311-318, 1976

2) Wayne LG, Doubek JR: Diagnostic key to mycobacteria encountered in clinical laboratories. Appl Microbiol 16:925-931, 1968

3) Williams SJ, Green M, Nicholls AC: An evaluation of the tuberculosis agglutination test. Brit J Dis Chest 72:138-142, 1978

4) Wayne LG: Mycobacterial speciation. In the Mycobacteria, source book. JP Kubica \& LG Wayne, ed. Marcel Dekker Inc, New York, 1984

5) Lind A, Ridell M: Mycobacterial species: Immunological classification. In the Mycobacteria, source book. JP Kubica \& LG Wayne ed, Marcel Dekker Inc, New York, 1984

6) Chaparas SD: Immunologically based diagnostic tests with tuberculin and other mycobacterial antigens. In the Mycobacteria, source book. JP Kubica \& LG Wayne ed, Marcel Dekker Inc, New York, 1984

7) Kim SJ, Bai GH, Lee SH, Hong YP, Kwon HH: A study of cell surface antigenic relationships among mycobacteria by enzyme linked immunosorbent assay. Tuberc Resp Dis (Kor) 33:147-157, 1986 